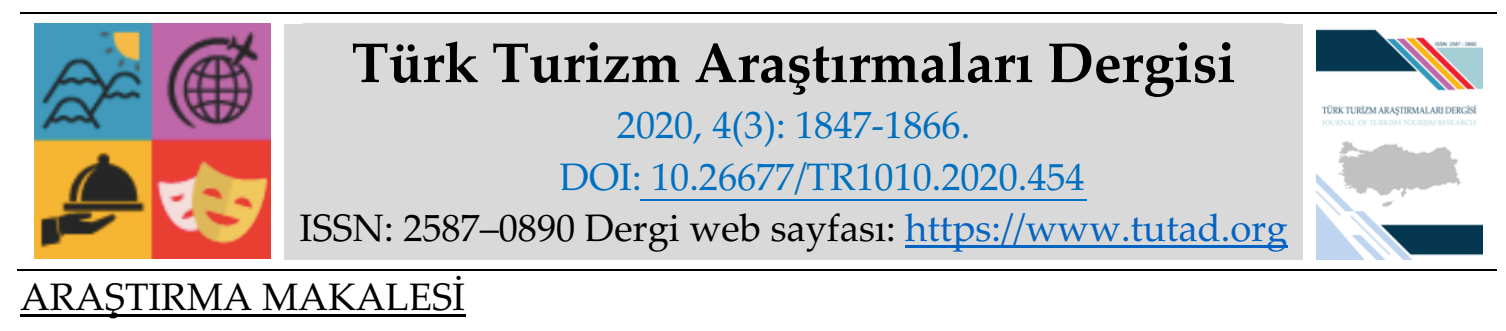

\title{
Seyahat Acentalarında Sürdürülebilirlik: Karadeniz Bölgesinde Faaliyet Gösteren Seyahat Acentaları Üzerine Bir İnceleme
}

Dr. Öğr. Üyesi Reşat ARICA, Adıyaman Üniversitesi, Turizm Fakültesi, Adıyaman, e-posta: rarica@adiyaman.edu.tr

ORCID: https://orcid.org/0000-0003-1238-7313

Dr. Öğr. Üyesi Neşe KAFA, Çanakkale Onsekiz Mart Üniversitesi, Gökçeada Uygulamalı Bilimler Yüksekokulu, Çanakkale, e-posta: nesekafa@comu.edu.tr ORCID: https://orcid.org/0000-0002-4153-5533

Öz

Araştırmanın temel amacı, seyahat acentalarının sürdürülebilirlik faaliyetlerine yönelik tutum ve davranışlarının belirlenmesidir. Araştırmanın verileri Türkiye'de Karadeniz Bölgesinde faaliyet gösteren acentalardan derlenmiştir. Bu kapsamda geçerli 250 anket verisi elde edilmiş ve bu veriler üzerinden tanımlayıcı analizler, açıklayıcı faktör analizi, doğrulayıcı faktör analizi ve ortalama analizleri gerçekleştirilmiştir. Elde edilen sonuçlar, acentalarda sürdürülebilirliğin (i) hizmet çıktılarını geliştirme, (ii) yerel paydaşlarla işbirliği ve paydaş seçim (iii) turistik deneyim ve üretimde ekolojik hassasiyet, (iv) tedarikçilerle ilişkiler, (v) tedarikçi tercihi, (vi) yerel işbirliği ve etki izleme, (vii) müşterilerle ilişkiler, (viii) sürdürülebilirliğe destek olarak isimlendirilen sekiz boyut odağında gerçekleştirildiğini göstermektedir. Bununla birlikte acentaların sürdürülebilirlik kapsamında uygulamalarının en fazla olduğu boyutun müşterilerle ilişkiler olduğu sonucuna ulaşılmıştır. Araştırma seyahat acentalarında yönetsel düzeyde sürdürülebilirliğe karşı tutum ve davranışlara ilişkin tespitlerin yapılması, geleceğe yönelik planlamalar ve yönetim stratejilerinin belirlenmesi adına araştırmayı izlek olması bağlamında önem arz etmektedir.

Anahtar Kelimeler: Seyahat Acentaları, Sürdürülebilirlik, Sürdürülebilir Turizm, Karadeniz. Makale Gönderme Tarihi: 25.02.2020

Makale Kabul Tarihi: 01.07.2020

\section{Önerilen Atıf:}

Arıca, R. ve Kafa, N. (2020). Seyahat Acentalarında Sürdürülebilirlik: Karadeniz Bölgesinde Faaliyet Gösteren Seyahat Acentaları Üzerine Bir İnceleme, Türk Turizm Araştırmaları Dergisi, 4(3): 1847-1866.

(c) 2020 Türk Turizm Araştırmaları Dergisi. 


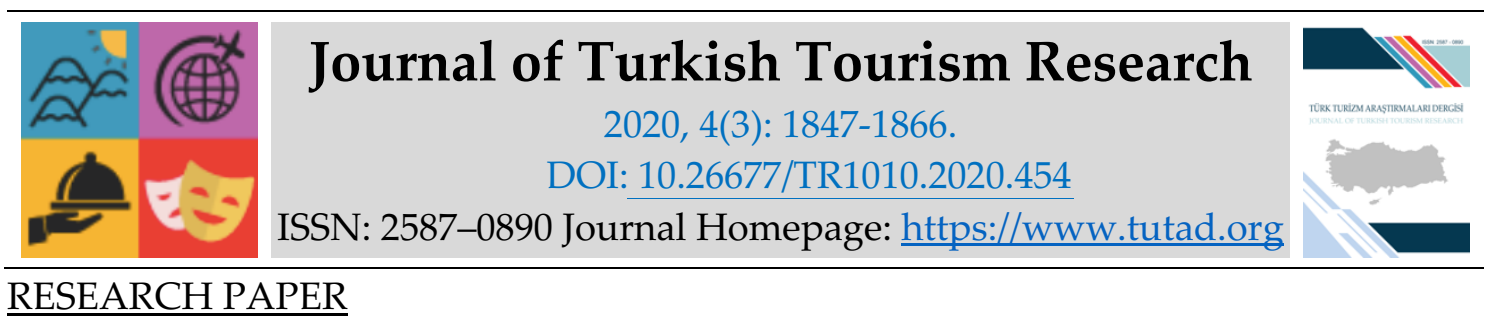

\title{
Sustainability in Travel Agencies: A Study on Travel Agencies Operating in the Black Sea Region
}

Assistant Prof. Dr. Reşat ARICA, Adıyaman University, Faculty of Tourism, Adıyaman, e-mail: rarica@adiyaman.edu.tr

ORCID: https://orcid.org/0000-0003-1238-7313

Assistant Prof. Dr. Neşe KAFA, Çanakkale Onsekiz Mart University, Gökçeada School of Applied Sciences, Çanakkale, e-mail: nesekafa@comu.edu.tr

ORCID: https://orcid.org/0000-0002-4153-5533

\begin{abstract}
The main purpose of the research is to determine the attitudes and behaviors of travel agencies towards sustainability activities. The data of the research was collected from the agencies operating in the Black Sea Region of Turkey. In this context, 250 valid survey data were collected and descriptive analysis, explanatory factor analysis, confirmatory factor analysis and mean value analyzes were performed. The results show that sustainability in travel agencies are realized in eight dimensions. These dimensions are named as follows: (i) improving service outcomes of agencies, (ii) cooperation with local stakeholders, and stakeholder selection (iii) ecological sensitivity in the production process of tour experience ecological sensitivity in the production of tour experience, (iv) relations with suppliers, (v) supplier preference, (vi) local cooperation and impact monitoring (vii) relationships with customers, (viii) supporting sustainability. However, it has been concluded that the most common dimension of agencies' practices within the scope of sustainability is relations with customers. Research is important in terms of determining attitudes and behaviours towards sustainability at the managerial level in the travel agencies, and its important in the context of pursuing the research in order to determine future planning and management strategies.
\end{abstract}

Keywords: Travel Agencies, Sustainability, Sustainability in Travel Agencies, Black Sea Region.

Received: 25.02 .2020

Accepted: 01.07.2020

\section{Suggested Citation:}

Arıca, R. and Kafa, N. (2020). Sustainability in Travel Agencies: A Study on Travel Agencies Operating in the Black Sea Region, Journal of Turkish Tourism Research, 4(3): 1847-1866.

(c) 2020 Türk Turizm Araştırmaları Dergisi. 


\section{Gíriş}

Turistik bölgelerin sahip olduğu doğal çekiciliklerin sayısı ve çeşitliliği, turistlerin bölgeyi tercihinde en önemli çekim gücünü oluşturmaktadır. Bu nedenle, doğal çevre sürekli olarak insanların seyahatlerini yönlendiren çekici bir güç, aynı zamanda turizm sektöründe vazgeçilmez kaynak olarak işlev görmektedir (Usta, 2001: 51-52). Dolayısıyla turizmin gelişmesi doğal alanların cazibe merkezi olarak korunmasına ve bu alanların tüketilmesine bağlıdır (Holden, 2008: 83). Ancak turizmin mevcut algılanış biçimi ekolojik dengenin bozulmasına neden olabilmektedir (Holden, 2008; Karacan, Karacan ve Güngör, 2015). Turizmin mevcut yapısı, insanların çevreye bıraktığı kimyasallar nedeniyle kirliliğin artmasına, enerji ihtiyacının karşılanması için fosil yakıt kullanımının artmasına, kıyıların ve yeşil alanların tahribine, su kaynaklarının kirlenmesi ve tükenmesine, taşıma kapasitesinde hızlı artış nedeniyle arazi kullanımında olumsuz değişikliklerle çevresel bozulmaların meydana gelmesine sebebiyet vermektedir (Fredericks, Garstea ve Monforte, 2008; Karacan vd. 2015). Bu bağlamda turistik girişimlerin ve hareketlerin doğal çevre üzerinde yararlı bir etkiye sahip olması muhtemel olmamakla beraber, turistik hareketlerin doğal çevreyi zarar verici etkisini asgari düzeye indirgemek mümkündür (Holden, 2008: 97).

Doğal ve kültürel çevrenin koruma-kullanma dengesi gözetilerek kullanımını öngören sürdürülebilir turizm (Kaypak, 2010: 94), doğal çevre ve ev sahibi toplulukların ihtiyaçlarına hitap eden, turizmin bugünkü ve gelecekteki ekonomik, sosyal ve çevresel etkilerini dikkate alan turizm anlayışı olarak tanımlanmaktadır (UNWTO, 2013). Sürdürülebilir turizm anlayışı doğal, kültürel ve ekonomik çevrenin korunmasının sektörel ölçekte bütüncül katılımla mümkün olduğunu ön görmektedir (Avcıkurt, 1997: 136). Bu kapsamda turizmde sürdürülebilirliğin seyahat acentaları, konaklama, yiyecek ve içecek, eğlence vb. işletmelerin kolektif katılımıyla mümkün olduğu savunulmaktadır (Tsaur ve Chen, 2018: 154). Seyahat acentaları arz ve talep öğeleri arasındaki aracılık rolüyle sektörde sürdürülebilirliğin sağlanmasında önemli bir işlev gördüğü söylenebilir (Tsaur ve Chen, 2018: 154; Mossaz ve Coghlan, 2017: 990). Bu durum seyahat acentalarının faaliyetleriyle, faaliyetlerinin yol açtığı çevresel etkiler arasında bir denge kurmaları gerekli kılmaktadır (Mossaz ve Coghlan, 2017: 990). Dolayısıyla, seyahat acentaları, turistik ürün ve hizmet üreticileriyle tüketiciler arasında aracı olarak, daha sürdürülebilir turizm uygulamaları için onların tutum ve davranışlarında, gerekli değişikliklerin başlatılmasında geniş olanaklara sahip olmakla birlikte büyük sorumluluk taşımaktadır (Budeanu, 2005: 93). Zira turistlerin gitmek istedikleri yere yönelik taleplerine bağlı olarak turistik bölgeler, yine seyahat acentaları tarafından pazarlanmaktadır (Carey, Gountas ve Gilbert, 1997: 426). Seyahat acentaları tarafından iyi yönetilen ve kontrollü bir biçimde gelişen turizm faaliyetleri ise doğal çevre üzerindeki olumsuz etkileri asgari düzeye indirgemekte ve turizm faaliyetlerinin uzun soluklu olmasına olanak tanımaktadır (Demir ve Çevirgen, 2006; Fredericks vd., 2008).

Seyahat acentalarının turizm sektöründe sürdürülebilirliğin sağlanmasındaki rolü ve uygulamaları çeşitli ulusal ve uluslararası araştırmalarda değerlendirilmiştir (Carey, Gounta ve Gilbert, 1997; Curtin ve Busby, 1999; Budeanu, 2005; Tepelus, 2005; Dimoska ve Petrevska, 2012; Erdoğan, 2012; Kilipiris ve Zardava, 2012; Almunawar, Muhammad ve Heru, 2013; Arıca, 2013; Erdoğan, 2014; Lozano, Arbulú ve Rey-Maquieira, 2015; Byrnes, Buckley, Howes ve Arthur, 2016; Hardeman, Font ve Nawijn, 2017; Sofronov,2017; Güzel ve Ön Esen, 2019; Gkoumas, 2019; MarinPantelescu, Tăchiciu, Căpuşneanu ve Topor, 2019). Çalışmaların bir kısmında seyahat acentalarının sürdürülebilir turizmle ilgili farkındalıklarına ve gerçekleştirdikleri uygulamalara 
odaklanılmıştır (Carey, Gountas ve Gilbert, 1997; Curtin ve Busby, 1999; Budeanu, 2005; Tepelus, 2005; Kilipiris ve Zardava, 2012; Sofronov, 2017; Marin Panteslescu vd. 2019; Gkoumas, 2019). Bu çalışmalarda seyahat acentalarının organize ettikleri tur faaliyetlerinin çevresel etkilerine ilişkin farkındalıklarının olduklarını belirlenmiştir (Curtin ve Busby, 1999; Hardeman vd., 2017). Araştırmaların bir kısmında ise seyahat acentalarının sürdürülebilir turizme yönelik farkındalıkları olmasına karşın, finansal kaygılar sebebiyle uygulamalara eğilim gösterme düzeylerinin sınırlı kaldığı tespit edilmiştir (Budeanu, 2007; Arıca, 2013; Marin Panteslescu vd. 2019). Literatürdeki bu çalışmalar doğrultusunda seyahat acentalarının turizm endüstrisindeki turistik hizmetlerin arzı ve talebi arasındaki rolü, turizmin sürdürülebilirlik amaçlarına ulaşılmasına, sosyal, ekonomik ve ekolojik kaynakların korunmasına sunacağı katkıları önemli hale getirmiştir (Tepelus, 2005: 99). Buna karşın alanyazında acentalarda sürdürülebilirlik konusunun gelişmiş ülkelerde veya turizmde gelişimi sağlayan ülkelerde daha yaygın kabul gördüğü, gelişmekte olan ve gelişmemiş ülkelerde turizm faaliyetlerinde esas amacın ekonomik fayda elde etme odağında konumlandırılmasından ötürü, ekolojik hassasiyetin yeterince gelişim göstermediği açıklanmaktadır (Tosun, 1999; Arıca, 2013). Mevcut çalışmada, gelişmekte olan bir ülke olarak Türkiye'de faaliyet gösteren seyahat acentalarında sürdürülebilirlik girişimlerinin belirlenmesi üzerine odaklanılmaktadır. Bu çıkış noktasından hareketle hazırlanan araştırmanın amacı, seyahat acentalarının sürdürülebilirlik faaliyetlerine yönelik tutum ve davranışlarının belirlenmesidir. Bu bağlamda Karadeniz Bölgesinde faaliyet gösteren seyahat acentalarının sürdürülebilirlik faaliyetlerine yönelik tutum ve davranışları incelenmiştir. Karadeniz bölgesi, seyahatlerinde doğa koruma ve çevre sorunlarına duyarlı oldukları gözlenen "eko turistler" açısından önemli kaynaklara sahiptir. Örneğin bölgede doğa yürüyüşü, rafting, endemik bitki gözlemciliği, kuş gözlemciliği, çiftlik turizmi vb. doğa turizmi etkinliklerinin yanında kültür turizmi, inanç turizmi, termal turizm ve sağlık turizm gibi alternatif turizm türlerine yönelik talebin ihtiyaçlarını karşılayabilecek potansiyel mevcuttur. Bu durum bölgede koruma-kullanma dengesi gözetilerek turistik aktivitelerin geliştirilmesini ve acentaların bu konudaki girişimlerini önemli kılmaktadır. Dolayısıyla araştırmada yapılan tespitler doğrultusunda seyahat acentalarında yönetsel düzeyde sürdürülebilirliğe karşı tutum ve davranışlara ilişkin tespitlerin yapılması, geleceğe yönelik planlamalar ve yönetim stratejilerinin belirlenmesi adına izlek olması bağlaminda önemlidir.

\section{LITERATÜR}

Seyahat acentaları, turistik ürün ve hizmetleri üretenlerle turistler arasında aracı fonksiyonu gören ve turistlerle olan ilişkiyi şekillendirmede önemli güce sahip işletmelerdir (Mossaz ve Coghlan, 2017: 989; Falcon ve Muoza, 1999: 108). Acentalar müşterilere pazarlanan eksiksiz bir tatil paketi oluşturmak için turizmle ilgili çeşitli hizmetleri bir araya getirir. Her bir paket tatil genellikle konaklama yerlerinden ulaştırma, geziler ve sosyal aktiviteler gibi etkinlikler veya aktivitelerden oluşur (Miller ve Twining-Ward, 2005: 269). Tüketiciler ve tur operatörleri arasındaki bilgi akışı tatil paketleri dağıtan seyahat acentaları tarafından sağlanır. Seyahat acentaları, tatil yerlerini ziyaret etmeden önce tüketicileri turizm ürünleri hakkında bilgilendirebilirler (Marin-Pantelescu vd., 2019:657). Bu bakımdan seyahat acentaları, turistik bölgelerin sürdürülebilirliği üzerinde önemli bir etkiye sahiptir (UNEP, 2005: 22). 
Carey ve Gountas (1997: 425) acentaların sürdürülebilir turizm faaliyetlerindeki başarısının tedarikçiler, aracılar, kamu sektörü ve tüketiciler gibi sektördeki tüm paydaşlarla etkin işbirliğine bağlı olduğunu vurgulamaktadır. Buna göre, bu paydaşların faaliyetleri doğal ve sosyo kültürel çevre üzerinde çeşitli etkiler yaratarak, turistik bölgenin sürdürülebilirliğini doğrudan etkilemektedir (Holden, 2008: 75). Kilipiris ve Zardava (2012: 47) acentaların söz konusu paydaşlarla ilişkisini tedarikçilerle ilişkiler ekseninde açıklarken, acentalarının tedarik zincirinde sürdürülebilirlik faaliyetlerini destekleyen işletmelerle iş birliği gerçekleştirmesinin gerekliliğine vurgu yapmaktadır. Acentaların temel tedarikçileri taşıma şirketleri, transfer şirketleri, konaklama işletmeleri, yiyecek ve içecek işletmeleri, eğlence işletmeleri ve araç kiralama şirketleridir (Fuller, 1994: 99-104). Seyahat acentalarının tur faaliyetlerinin tüm bileşenlerinde performansın iyileştirilmesi ve sürdürülebilirlik politikalarının etkin bir şekilde uygulanması söz konusu tedarikçilerle yakın çalışmasını gerektirmektedir (Miller ve Twining-Ward, 2005: 270). Tedarik zinciri yönetimi açısından sürdürülebilirlik gereksinimlerini iyileştirmek için acentaların satın alma gücünü kullanarak, tedarikçileri seçim kriterlerinin belirlenmesi, hizmet sağlayıcıların seçimini sürdürülebilirlik ekseninde gerçekleştirmesi ve tedarikçilerle sürdürülebilirlik ilkeleri doğrultusunda yazılı sözleşmelerin gerçekleştirilmesinin gereklidir (Miller ve Twining-Ward, 2005: 270; Van Wijk ve Persoon, 2006: 387). Bu durum, acentaların sürdürülebilir gelişim kapsamında çevresel ve kültürel kaynakların korunmasına gözle görülür bir katkıda bulunmalarını sağlamaktadır (Güzel ve Öz Esen, 2019: 208). Acentalarda sürdürülebilirliğin bir diğer kriteri Garrod'un (2003: 125-126) ifade ettiği üzere turistik bölgelerle ilişkilerdir. Turistik bölgelerle ilişkiler acentaların bölgede gerçekleştirilen turizm faaliyetlerinin yoğun ve geri dönüşümü mümkün olmayan olumsuz etkilere yol açmasını engellemesi bakımından oldukça önemlidir. Buna göre, turistik bölge seçim sürecinde acentaların sürdürülebilirlik ilkelerini dikkate almaları beklenmektedir.

Seyahat acentaları turistik bölge tercihi yaparken, turizmin yerel ekonomi, sosyo kültürel yapı ve çevresel kaynaklar üzerindeki etkilerini dikkate almalıdır (Miller ve Twining-Ward, 2005: 267; Nylander ve Hall, 2005: 18). Böylece turistik bölgedeki en önemli rekabet kaynağı olan tarihi yapılar ve doğal çekiciliklerin kalitesi korunarak turistik bölgede meydana gelen olumsuz etkiler azaltılabilecektir (Bahar ve Kozak, 2005: 102). Aynı zamanda tur gereksinimlerinin yerel paydaşlardan sağlanması bölgede iş olanaklarının üretilmesi, bölgeye doğrudan ve dolaylı olarak maddi yarar sağlanmasını olanaklı hale getirecektir (Anwar, 2012: 4). Getz ve Timur'un (2005) ifade ettiği üzere acentaların yerel toplumu dikkate alması sürdürülebilir gelişim açısından önemlidir. Örneğin yöre sakinlerinin evlerinin bir bölümünü turistlere kiralaması, talebin karşılanmasına yardımcı olurken diğer taraftan yerel halkın turizme etkin katılımını sağlayarak kültürel ve ekonomik paylaşımı arttıracaktır (Aşan ve Yılmazdoğan, 2012). Yerel toplumun değerleri ve beklentileri dikkate alınmadan, yapılan salt ekonomik gelişim üzerine odaklanan yaklaşımların başarılı olmasının güç olduğuna dikkat çekmektedir. Bu nedenledir ki, turizmin olumlu yönlerinin geliştirilmesi, sürdürülebilir turizm şeklinin gerçekleşebilmesi ve olumlu etkilerin en üst düzeye çıkarılması için yerel halkın dikkate alınması, onların görüş ve önerileri doğrultusunda turistik ürün planlamalarının yapılması gereklidir (Gunn, 1988). Bu sayede, yerel ekonomik faydayı optimize ederek, doğal çevreyi koruyarak ve ziyaretçilerin daha kaliteli deneyimler yaşayacağı çevreler inşa ederek yerel halkın yaşam seviyesini yükseltilmesi olanaklı hale gelmektedir (Choi ve Sirakaya, 2006: 1275). Benzer şekilde acentaların sürdürülebilir gelişimi destekleyici bir faaliyet olarak turistik bölgeye bağış yapması, ayrıca turistleri bağış yapmaya ve bölgeden turistik ürün satın almaya teşvik etmesi önemlidir (Ashley ve Ashton, 2006: 4). 
Artan turizm talebi sonucunda turistik faaliyetlerin doğal ve sosyo kültürel çevrede yol açtığ olumsuz etkilerin azaltılması konusunda seyahat acentalarına özellikle ürün üretimi ve yönetimi sürecinde büyük görevler düşmektedir (Fredericks vd., 2008). TUI'ye göre acentalar turistik bölgelerdeki doğal çevrenin durumunu izlemeli ve tur faaliyetlerini bu eksende planlamalıdır. Buna göre çevresel kriterleri oluşturan; yüzme suyu ve plaj kalitesi, su tasarrufu önlemleri, atık su yönetimi, atık yönetimi, enerji tasarrufu önlemleri, trafik, hava, gürültü ve iklim değişikliği, açık alan planlama, doğa, türler ve hayvanların korunması gibi değişkenler dikkate alınarak ürün üretimi gerçekleştirilmelidir (UNEP, 2005: 24). Turistik ürün üretimi ve yönetiminde çevresel yük ve kaynak kullanımını azaltarak doğal çevreye duyarlı üretimin gerçekleştirilmesi (Roy, 2000: 289), turizmin doğal çevre üzerindeki etkilerinin azaltılması mümkün hale getirmektedir (Holden, 2008: 84; Karacan vd., 2015: 5). Buna göre ürün üretim ve yönetim sürecinin her aşamasında doğal kaynaklar ve sosyo kültürel özelliklerin dikkate alınması önemlidir (Arıca, 2017).

Budeanu (2007) ve Arıca (2013) acentaların sürdürülebilirliğe katkısını iç yönetim faaliyetleri olarak adlandırılan ofis içerisinde gerçekleştirdiği faaliyetlerle ilişkilendirmektedir. Bu kapsamda araştırmacılar işletmelerin sürdürülebilirlik faaliyetlerini kendi çekirdek yapılarıyla bütünleştirmesinin önemine dikkat çekmektedir. İç yönetim faaliyetlerinin etkinlik ve verimliliği sürdürülebilirlik politikalarının belirlenip, faaliyetlerin bu odakta yönetilmesiyle ilişkilidir (Poon, 1993: 154; Budeanu, 2000). İç yönetim faaliyetlerinde atık ayrıştırma, enerji ve su tasarrufu, geri dönüşümlü kullanım, personel bilgilendirme önemli değişkenler olarak açıklanmaktadır (Wijk ve Pearson, 2006; Budeanu, 2007). İç yönetim faaliyetleriyle birlikte turistik faaliyetlerin temel öğesi olan turistlerde sosyo kültürel değerlere ve doğal çevreye yönelik farkındalığın oluşturulması sürdürülebilir turizm faaliyetlerinin başarısında önemlidir (Poon, 1993: 67; Schwartz, Tapper ve Font, 2008: 301). Bir tüketici olarak turistlerde çevresel farkındalığın oluşturulması turistlerin neden oldukları olumsuz çevresel etkilerin azaltılması için bilgilendirilme ve eğitim vasıtasıyla turistlerde sürdürülebilirlik faaliyetlerine yönelik farkındalık oluşturulabilecektir (Font ve Cochrane, 2005: 37). Bununla birlikte turistlerden alınan geri bildirimlerin dikkate alınması önemlidir. Bu faaliyetlerin tümünde seyahat acentaları eğitici gibi davranmalı ve çevrenin nasıl korunacağını turistlere gösterebilmelidir (Cavlek, 2002: 51-53; Kilipiris ve Zardava, 2012: 47). Örneğin Marin-Pantelescu vd., (2019) yaptıkları çalışmalarında seyahat acentaları, turistleri seyahat edecekleri yerlerdeki çevre koruma ve geri dönüşüm kuralları hakkında bilgilendirdikleri tespit edilmiştir. Ayrıca Fredericks vd.'ne (2008: 10) göre acentaların söz konusu alanlarda atacağı stratejik adımlar turizmin çevreye olan olumsuz etkilerinin azaltılmasına yardımcı olmakla beraber, turistik bölgelerin sürdürülebilirliğinde önemli etkileri bulunmaktadır.

Acentaların söz konusu alanlarda sürdürülebilir turizm faaliyetlerine desteği ve girişimleri işletme hizmet çıktılarının geliştirmesini olanaklı kılmaktadır. Ancak Marin-Pantelescu vd., (2019) yaptıkları çalışmada işletmelerin sürdürülebilir turizm kriterlerine uymalarının finansal sonuçları konusunda endişe duydukları belirlenmiştir. Bunun aksine Bagur-Femenias vd. (2013)'nin yaptıkları çalışmada çevre uygulamalarının benimsenmesinin küçük seyahat acentalarının rekabet gücünü arttırdığını saptamıştır. Özellikle gelişmiş çevre stratejilerinin benimsenmesinin, seyahat acentalarının kendilerini rakiplerinden farklılaştırarak operasyonel maliyeti azaltmasına ve pazar payını artırmasına izin verdiğini tespit edilmiştir. Alternatif turizm formları, ucuz paket turlarla gidilen tatil köyleri gibi bilindik turizm anlayışı yerine golf turizmi, av turizmi, kültür turizmi, macera turizmi, doğa temelli turizm gibi niş seçeneklerle kitle turizm 
faaliyetlerine seçenekler sunarak pazarda ürün çeşitliliği oluşturmaktadır (Weaver, 2001: 4-12). Seyahat sektöründeki rekabet öte yandan talebin değişen yapısı ve eğilimleri acentaları kitle üretimlere nispeten daha küçük turistik gruplara hizmet eden farklılaştırılmış ürün oluşturmaya yöneltmektedir (Stankova, 2010: 760). Acentalar da kitlesel üretim odağında koşullanan ve müşterilerini belli bir turistik ürün seçeneğini satın almaya zorunlu tutan üretimlerden uzaklaşarak, farklılaştırılmış ve kişiselleştirilmiş hizmetler oluşturmak ve ürettikleri hizmetleri pazara sunmak yolunu benimsemektedir (Arıca, 2019: 510). Aynı zamanda ekolojik üretimler de acentaların ürün yelpazesini çeşitlendirerek müşterilerin satın alması için teşvik unsuru olmaktadır (Poel, Schamphelaere ve Wets, 2004: 53). Kieninger, Gugerell ve Penker (2016), acentaların yerel gelir yaratmak ve turizm varış noktasını iyileştirmek için farklı turistik ürünler geliştirdiğine yer vermektedir. Peru'daki eko-turizm şirketi olan Rainforest Expeditions, faaliyetlerinde yerli topluluğun, emek, barınma ve yiyecek sağlaması ile elde edilen kârın yüzde 60'inı yerli halk elde etmektedir. Ancak faaliyetler iyi yönetilemediğinde ise bu kazanç azalabilmektedir. Örneğin, Nepal'in Annapurna bölgesinde, eko-tur operatörleri yerel kaynakların yetersizliğinden dolayı eko-turistlerin ihtiyaçlarını karşılamak için birçok yabancı ürün ithal etmek zorunda kalmaktadır. Sonuç olarak, turistlerin harcamalarının sadece yüzde 10 'u yerel ekonomiye katkı sağlamaktadır (www.prb.org). Aynı zamanda ekolojik turların oluşturulması acentaların turist gruplarının farklılaşan ihtiyaç ve taleplerine karşıllık vermesi adına önemlidir (Stankova, 2010: 762). Bu sayede Acentalar da rekabet avantajı elde etmektedir. Örneğin Hotelplan ekolojik kriterleri dikkate alarak ürün geliştirmekte ve bu sayede rekabet avantajı elde etmeyi amaçlamaktadır.

\section{ARAŞTIRMANIN YÖNTEMI}

\section{Araştırmanın Amacı ve Önemi}

Seyahat acentalarının sürdürülebilirlik faaliyetlerine yönelik tutum ve davranışlarının belirlenmesi araştırmanın temel amacıdır. Bu odakta seyahat acentalarında yönetsel düzeyde sürdürülebilirliğe karşı tutum ve davranışlara ilişkin alanlarının tespiti, geleceğe yönelik planlamalar ve yönetim stratejilerinin belirlenmesi adına araştırmayı izlek olması bağlamında önemli kılmaktadır.

\section{Araştırmanın Evren ve Örneklemi}

Araştırmanın evrenini Karadeniz Bölgesinde faaliyet gösteren seyahat acentaları oluşturmaktadır. Karadeniz bölgesi ülkemizde doğaya yönelik turizm çeşitlerinin yoğun olarak gerçekleştiği alanlara sahipken, bölge ekolojik çeşitlilik yönünden de oldukça zengindir (Atasoy vd. 2009: 1). Bununla birlikte ülkesel ölçekte korunan alanların \%11'lik kısmı bölgede bulunmaktadır (www.milliparklar.gov.tr). Bu durum mevcut kaynakların korunması adına Karadeniz Bölgesinde ekolojik hassasiyetin gerekliliğini elzem kılmaktadır. Bu kapsamda araştırmada, bölgede bulunan A, B ve C Grubu seyahat acentalarına odaklanılmıştır. Araştırmada örnekleme yöntemi olarak olasılığa dayalı olmayan örnekleme yöntemlerinden olan kolayda örnekleme yöntemi tercih edilmiştir. Bu örnekleme tekniğinde ankete cevap vermek isteyen tüm öğrenciler örnekleme dâhil edilmektedir. TÜRSAB verilerine göre Ekim 2019 itibariyle Karadeniz Bölgesinde yer alan 18 ilde faaliyet gösteren toplam 549 seyahat acentası bulunmaktadır. Mart-Ağustos 2019 tarihleri arasında gerçekleştirilen uygulama nihayetinde 
toplamda 262 anket elde edilmiştir. 12 anket formu hatalı ve eksik veri içerdiğinden araştırma kapsamı dışında tutulmuş ve kullanılabilir olduğu tespit edilen 250 geçerli anket formu üzerinden analizler gerçekleştirilmiştir.

\section{Veri Toplama Aracı ve Verilerin Analizi}

Araştırmada veri toplama aracı olarak anketten faydalanılmıştır. Anket, nicel araştırmalar içerisinde sıklıkla yararlanılan, cevaplayıcının daha önce belirlenmiş bir sıralamada ve yapıda oluşturulan sorulara karşılık vermesiyle veri elde etme yöntemidir (Altunışık, Coşkun, Bayraktaroğlu ve Yıldırım, 2012: 80). Araştırmada kullanılan anket veri formu iki bölümden oluşmaktadır. Anket formunun birinci bölümünde, seyahat acentalarının sürdürülebilirlik faaliyetlerine yönelik tutum ve davranışlarının belirlenmesine yönelik ifadeler yer almaktadır. Acentaların sürdürülebilirlik faaliyetlerine yönelik tutum ve davranışlarının belirlenmesine yönelik geliştirilen ifadeler Goffi, Masiero ve Pencarelli (2018) çalışmasından uyarlanmıştır. Bu kapsamda uzman görüşü alınmış ve ölçüm aracında 41 ifadeye yer verilmiştir. İfadelerin ölçümünde beşli likert derecelendirmeden yararlanılmıştır (1 Kesinlikle Katılmıyorum, 2 Katılmıyorum, 3 Fikrim Yok, 4 Katılıyorum, 5 Kesinlikle Katılıyorum). Anket veri toplama aracının ikinci bölümünde işletmelerin faaliyet yapısına dair özelliklerinin tespitine yönelik sorulara yer verilmiştir.

Çalışmada elde edilen veriler tanımlayıcı istatistikler, ortalama analizi, açıklayıcı ve doğrulayıcı faktör analiziyle incelenmiştir. Öncelikle, tanımlayıcı analizlerle işletmelerin faaliyet yapısına dair özellikler sıklık ve yüzde değerleri belirlenmiştir. İkinci aşamada, veri seti üzerinde öncelikle Açıklayıcı faktör analizi (AFA), ardından Doğrulayıcı faktör analizi (DFA) uygulanarak modelin uygunluğu sınanmıştır. Üçüncü aşamada katılımcıların faktörlere ilişkin tutum ve davranış ortalamaları değerlendirilmiştir.

\section{ANALIZ ve BULGULAR}

\section{İşletme Özelliklerine İlişkin Bulgular}

Araştırmada işletme özelliklerine yönelik elde edilen bulgulara göre; araştırma formunu yanıtlayan işletme çalışanlarının büyük bir bölümü $(\% 68,4)$ işletme sahibi ve yöneticisidir. Bununla birlikte acentaların yarısından fazlasının $(\% 55,6) 2011$ yılından sonra faaliyet göstermeye başladığ1 ve büyük bir bölümü şehir merkezlerinde $(\% 74,8)$ bulunduğu belirlenmiştir. Ayrıca araştırmaya katılan işletmelerin yarısından fazlasının sürdürülebilirlik noktasında izlek olarak faydalanabilecekleri yazılı sürdürülebilirlik prosedür veya ilkelerine sahip olmadıkları görülmüştür. İşletmelerin yıllık müşteri sayısına ilişkin bulgular, işletmelerin küçük ölçekli müşteri kitlelerine sahip olduklarını göstermektedir. İşletmelerde çalışan sayısına ilişkin bulgular birçok işletmede 1 ve 5 arasında birey istihdam edildiğini, işletmelerin yarıdan fazlasında çalışanların tümünün yerel halktan olduğu belirlenmiştir. Bununla birlikte işletmelerde çalışan erkek sayısı kadınlara nispeten yüksek olmasında karşın, acentaların \% 14 'ünde kadın çalışanların oranının erkeklerden fazla olduğu görülmektedir. Acentaların $\% 18$ 'inde sadece erkeklerin istihdam edildiği ve \%4'ünün ise çalışanlarının sadece kadınlardan oluştuğu görülmektedir. 
Tablo 1: İşletme Özelliklerine İlişkin Bulgular

\begin{tabular}{lcccccc}
\hline & Sıklık & Yüzde & Sıklık & Yüzde \\
\hline \multicolumn{1}{c}{ İşletmenin Kuruluş Yılı } & & \multicolumn{2}{c}{ Çalışan Sayısı } \\
\hline 2000 ve öncesi & 43 & 17,2 & $1-5$ & 115 & 46,0 \\
\hline $2001-2010$ & 68 & 27,2 & $6-10$ & 78 & 31,2 \\
\hline $2011-2019$ & 139 & 55,6 & $11-15$ & 37 & 14,8 \\
\hline & & & $16-20$ & 20 & 8,0
\end{tabular}

\begin{tabular}{|c|c|c|c|c|c|}
\hline İşletmenin Konumu & & & Yerel Halktan Çalışan & & \\
\hline İl & 187 & 74,8 & Hepsi & 132 & 52,8 \\
\hline İlçe & 63 & 25,2 & \%99-51 Yerel Halk & 76 & 30,4 \\
\hline $\begin{array}{l}\text { Yazılı Sürdürülebilirlik } \\
\text { İlkelerine Sahip Misiniz? }\end{array}$ & & & $\% 50-\% 0$ Yerel Halk & 42 & 16,8 \\
\hline Evet & 90 & 36,0 & Çalışanların Cinsiyeti & & \\
\hline Hayır & 160 & 64,0 & \%0 Kadın \%100 Erkek & 46 & 18,4 \\
\hline $\begin{array}{l}\text { Yıllık Müşteri Sayısı } \\
\text { (Son } 5 \text { Yılın Ortalaması) }\end{array}$ & & & \%20 Kadın \%80 Erkek & 27 & 10,8 \\
\hline 5000 ve alt1 & 112 & 44,7 & \%25 Kadın \%75 Erkek & 17 & 6,8 \\
\hline $5001-10000$ & 59 & 23,6 & \%33 Kadın \%67 Erkek & 19 & 7,6 \\
\hline 10001 ve üstü & 29 & 11,5 & \%40 Kadın \%60 Erkek & 36 & 14,4 \\
\hline Yanit Yok & 50 & 20,0 & \%50 Kadın \%50 Erkek & 65 & 26,0 \\
\hline $\begin{array}{c}\text { Katılımcının İşletmedeki } \\
\text { Pozisyonu }\end{array}$ & & & \%60 Kadın \% 40 Erkek & 9 & 3,6 \\
\hline İşletme Sahibi/Ortağ1 & 56 & 22,4 & \%67 Kadın \%33 Erkek & 7 & 2,8 \\
\hline İşletme Yöneticisi & 115 & 46,0 & \%75 Kadın \%25 Erkek & 5 & 2,0 \\
\hline Seyahat Danışmanı & 66 & 26,6 & \%80 Kadın \%20 Erkek & 9 & 3,6 \\
\hline Muhasebe Personeli & 13 & 5,0 & \%100 Kadın \% 0Erkek & 10 & 4,0 \\
\hline & & & TOPLAM & 250 & 100 \\
\hline
\end{tabular}

\section{Açıklayıcı Faktör Analizine İlişkin Bulgular}

Araştırmada aralarında yüksek korelasyon olan değişkenler setinin bir araya getirilmesi amacıyla faktör analizi uygulanmıştır. Açıklayıcı faktör analizi (AFA), veri matrisindeki maddelerin puan değerleri arasındaki ilişkilerden yararlanarak az sayıda alt boyut belirlemeyi amaçlayan yöntemdir (Özdamar, 2016: 134). Yapılan açıklayıcı faktör analizine göre, sekiz faktörlü bir yapı elde edilmiştir. Bunlar; (i) hizmet çıtılarını geliştirme, (ii) yerel paydaşlarla işbirliği ve paydaş seçimi (iii) turistik deneyim ve üretimde ekolojik hassasiyet, (iv) tedarikçilerle ilişkiler, (v) tedarikçi tercihi, (vi) yerel işbirliği ve etki izleme, (vii) müşterilerle ilişkiler, (viii) sürdürülebilirliğe destek olarak isimlendirilmiştir.

Faktör seti belirlenmeden, veri setinin faktör analizi için uygunluğu değerlendirilmiştir. Bu bağlamda korelasyon matrisinde, 0.30 'un altında olan ilişki katsayılarının olmadığı, KMO değerinin 0.912 ve Bartlett Küresellik Testi verisi $p<, 000$ olarak hesaplanmıştır. Her bir faktör için ortak faktör varyanslarına bakıldığında 0.50 'nin altında değer olmadığı belirlenmiştir. Faktör yapısını belirlemek ve faktörleştirme sonuçlarını yorumlamak amacıyla varimax yöntemiyle faktörlerin rotasyonu yapılmıştır. İlk analiz neticesinde tek bir faktör altında kümelenen 'turistik bölgenin taşıma kapasitesini göz önüne alarak tur faaliyetlerine katılacak turist sayısını sinırlamayı önemseriz' ifadesi analiz dışı bırakılmış, AFA tekrarlanmıştır. Yinelenen analizler neticesinde, birden fazla faktöre yük veren ifade tespit edilmiştir (personelimize doğal çevreye duyarlı 
uygulamalara konusunda eğitim veririz). İfade ölçüm modelinden atılarak analiz tekrarlanmış, tüm uyum koşulları sağlanırken benzer şekilde 'sürdürülebilirlik işletme imajının iyileştirilmesinde önemli role sahiptir' ifadesi iki faktörde 0.10 'dan daha yakın yük taşıdığından ifade analiz dışı bırakılmıştır. Yinelenen analizler neticesinde ölçüm modelinde faktör analizi için uyumlu, binişik yük taşıyan ifadenin olmadığı, öz değeri birden büyük sekiz faktörlü bir yapının varlığı belirlenmiştir. Analize dâhil edilen değişkenlerin toplam varyansın 67.013'ünü açıkladığ belirlenmiştir. Ölçeğin açıkladığı varyansın $0,30^{\prime}$ dan daha düşük olmaması kriterinden hareketle (Bayram, 2012), çok faktörlü desende açıklanan varyansın standartların üzerinde olduğu görülmektedir.

Tablo 2: Açıklayıcı Faktör Analizine İlişkin Bulgular

\begin{tabular}{|c|c|c|c|c|}
\hline Faktörler ve İfadeler & $\begin{array}{l}\text { Faktör } \\
\text { Yükleri }\end{array}$ & Özdeğer & $\begin{array}{c}\text { Açılanan } \\
\text { Varyans }\end{array}$ & $\begin{array}{l}\text { Cronbach's } \\
\text { Alpha } \\
\text { Katsayısı }\end{array}$ \\
\hline 1. Hizmet Çıktılarını Geliştirme & & 13.978 & 36.784 & .913 \\
\hline $\begin{array}{l}\text { Sürdürülebilirlik, müşteri memnuniyetini sağlamak adına } \\
\text { önemlidir. }\end{array}$ & .828 & & & \\
\hline $\begin{array}{l}\text { Sürdürülebilirlik, işletmenin pazarlama fırsatları elde etmesi } \\
\text { adına önemlidir. }\end{array}$ & .809 & & & \\
\hline $\begin{array}{l}\text { Sürdürülebilirlik, işletmenin olumlu tanıtımında önemli role } \\
\text { sahiptir. }\end{array}$ & .770 & & & \\
\hline $\begin{array}{l}\text { Sürdürülebilirlik, birlikte çalıştığımız paydaşlar tarafından } \\
\text { önemli kabul edilir. }\end{array}$ & .738 & & & \\
\hline $\begin{array}{l}\text { Sürdürülebilirliği, işletme stratejimizin bir parçası olarak } \\
\text { kabul ederiz. }\end{array}$ & .706 & & & \\
\hline $\begin{array}{l}\text { Sürdürülebilirliği, işletme yönetim sürecinin bir parçası } \\
\text { olarak görürüz. }\end{array}$ & .653 & & & \\
\hline $\begin{array}{l}\text { İşletmemiz turistik bölgelerin sürdürülebilirliğinde önemli } \\
\text { bir role sahiptir. }\end{array}$ & .540 & & & \\
\hline $\begin{array}{l}\text { Sürdürülebilirlik, işletmemizin temsil ettiği değerlerin } \\
\text { içeriğini oluşturur. }\end{array}$ & .531 & & & \\
\hline $\begin{array}{l}\text { Sürdürülebilirlik, turizm pazarında farklılaşmak adına } \\
\text { önemlidir. }\end{array}$ & .475 & & & \\
\hline 2. Yerel paydaşlarla işbirliği ve paydaş seçimi & & 2.601 & 6.844 & .885 \\
\hline $\begin{array}{l}\text { Tur faaliyetleri sırasında müşterilerimizin } \\
\text { restoranlarda yerel ürünler tercihini teşvik ederiz. }\end{array}$ & .749 & & & \\
\hline $\begin{array}{l}\text { Tur faaliyetleri sırasında müşterilerimizi yerel üreticiler } \\
\text { tarafından üretilen (el yapımı ürünler ve hediyelik eşyalar } \\
\text { gibi) ürünler satın almasını teşvik ederiz. }\end{array}$ & .740 & & & \\
\hline $\begin{array}{l}\text { Yerel işgücü tercihlerini belirlediğimiz standartlar (iş } \\
\text { gücünün çevresel hassasiyet ve çevre koruma bilgisi gibi) } \\
\text { doğrultusunda yapmaya özen gösteririz. }\end{array}$ & .739 & & & \\
\hline $\begin{array}{l}\text { Tur faaliyetlerinde yerel işgücünden faydalanılmayı } \\
\text { önemseriz. }\end{array}$ & .710 & & & \\
\hline Tur faaliyetlerinde yerel ürünleri tercih etmeyi önemseriz. & .594 & & & \\
\hline $\begin{array}{lllll}\text { 3. } & \begin{array}{l}\text { Turistik deneyim ve üretimde ekolojik } \\
\text { hassasiyet }\end{array} \\
\end{array}$ & & 2.082 & 5.480 & .848 \\
\hline $\begin{array}{l}\text { İşletmemiz tarafından organize edilen tur faaliyetlerinin } \\
\text { çevresel etkilerini izlemeye önem veririz. }\end{array}$ & .770 & & & \\
\hline $\begin{array}{l}\text { Tur faaliyetlerinde tercih edilen konaklama işletmelerin } \\
\text { doğal çevreye duyarlı olmasını önemseriz. }\end{array}$ & .719 & & & \\
\hline $\begin{array}{l}\text { Tur faaliyetlerinde tercih edilen taşıma araçlarının doğal } \\
\text { çevreye etkisi düşük araçlar olmasını önemseriz. }\end{array}$ & .710 & & & \\
\hline $\begin{array}{l}\text { İşletme olarak eko-etiketleme programlarına katılmayı } \\
\text { önemseriz. }\end{array}$ & .670 & & & \\
\hline
\end{tabular}




\begin{tabular}{|c|c|c|c|c|}
\hline $\begin{array}{l}\text { İşletmemiz turistik bölgeyi korumaya yönelik projeleri } \\
\text { desteklemeyi önemser. }\end{array}$ & .650 & & & \\
\hline $\begin{array}{l}\text { Tur faaliyetlerinde grup sayısını çevreye zarar vermeyecek } \\
\text { aralıkta belirlemeye dikkat ederiz. }\end{array}$ & .554 & & & \\
\hline 4. $\quad$ Tedarikçilerle İlişkiler & & 1.663 & 4.376 & .865 \\
\hline $\begin{array}{l}\text { Sürdürülebilirlik konularına (ilke ve politikalarımızı) web } \\
\text { sitemizde yer veririz. }\end{array}$ & .844 & & & \\
\hline $\begin{array}{l}\text { Sürdürülebilirlik konularına (ilke, politika, görsel ve bilgi) } \\
\text { broşürlerimizde yer veririz. }\end{array}$ & .772 & & & \\
\hline $\begin{array}{l}\text { İşletmemizin sürdürülebilirlik faaliyetlerini periyodik } \\
\text { olarak raporlamaya önem veririz. }\end{array}$ & .670 & & & \\
\hline $\begin{array}{l}\text { İşletmemiz yerel yönetimlerin sürdürülebilir turizm } \\
\begin{array}{l}\text { konusundaki farkındalık geliştirme girişimlerini } \\
\text { desteklemeye çalışır. }\end{array}\end{array}$ & .571 & & & \\
\hline $\begin{array}{l}\text { Birlikte çalıştığımız işletmelerin farkındalıklarını sağlayacak } \\
\text { sürdürülebilir turizm rehberleri oluşturmaya önem veririz. }\end{array}$ & .565 & & & \\
\hline $\begin{array}{l}\text { Faaliyetlerimize ilişkin belirlediğimiz sürdürülebilirlik } \\
\text { standartlarına uyma konusunda tedarikçilerimizle sözleşme } \\
\text { yapmaya önem veririz. }\end{array}$ & .521 & & & \\
\hline 5. $\quad$ Tedarikçi Tercihi & & 1.329 & 3.497 & .675 \\
\hline $\begin{array}{l}\text { Tur faaliyetlerinde tercih edilen konaklama işletmelerinin } \\
\text { sahipliğinin yerel halka ait olmasını önemseriz. }\end{array}$ & .656 & & & \\
\hline $\begin{array}{l}\text { Sürdürülebilirlikten, maliyet azaltma stratejisi olarak } \\
\text { yararlanırız. }\end{array}$ & .647 & & & \\
\hline $\begin{array}{l}\text { Tur faaliyetine katılan müşterilerimizi yerel seyahat } \\
\text { acentalarından gezi satın almaya yönlendiririz. }\end{array}$ & .548 & & & \\
\hline 6. Yerel işbirliği ve Etki izleme & & 1.563 & 4.113 & .782 \\
\hline $\begin{array}{l}\text { İşletmemiz yerel ölçekli sivil toplum kuruluşlarından } \\
\text { çevresel hassasiyeti sağlamak adına bilgi almayı } \\
\text { önemsemektedir }\end{array}$ & .721 & & & \\
\hline $\begin{array}{lccc}\text { İşletmemiz } & \text { sivil toplum } & \text { örgütleriyle } & \text { işbirliği } \\
\text { gerçekleştirmeyi önemsemektedir. } & & \end{array}$ & .680 & & & \\
\hline $\begin{array}{l}\text { İşletmemiz tarafından organize edilen tur faaliyetlerinin } \\
\text { sosyo-kültürel etkilerini izlemeye önem veririz. }\end{array}$ & .636 & & & \\
\hline İşletme olarak yerel işbirliklerini desteklemeye önem veririz. & .498 & & & \\
\hline 7. Müşterilerle İlişkiler & & 1.223 & 3.218 & .831 \\
\hline $\begin{array}{l}\text { İşletmemizde müşterilerimizin tur faaliyetleri esnasında } \\
\text { uyması gereken davranış kuralları geliştirilmiştir. }\end{array}$ & .654 & & & \\
\hline $\begin{array}{l}\text { İşletme olarak müşterilerimizin sürdürülebilir turizm } \\
\text { konusundaki farkındalığının artmasına yönelik girişimlerde } \\
\text { bulunuruz. }\end{array}$ & .554 & & & \\
\hline $\begin{array}{l}\begin{array}{l}\text { Müşterilerimize yerel kültüre } \\
\text { önemseriz. }\end{array} \\
\text { on }\end{array}$ & .469 & & & \\
\hline 8. $\quad$ Sürdürülebilirliğe Destek & & 1.027 & 2.702 & .604 \\
\hline $\begin{array}{l}\text { İşletmemiz yerel paydaşlardan çevresel hassasiyeti } \\
\text { sağlamak adına bilgi almaya önem verir. }\end{array}$ & .611 & & & \\
\hline $\begin{array}{l}\text { İşletmemiz turistlerin gönüllü olarak yaptığı bağışları } \\
\text { destekleme konusunda duyarlıdır. }\end{array}$ & .569 & & & \\
\hline $\begin{array}{l}\text { Açıklanan Toplam Varyans } \\
\text { (Total Variance Explained) }\end{array}$ & \multicolumn{4}{|c|}{67.013} \\
\hline Toplam Cronbach's Alpha Güvenirlilik Katsayısı (\%) & \multicolumn{4}{|c|}{.950} \\
\hline Kaiser-Meyer-Olkin (KMO) & \multicolumn{4}{|c|}{.912} \\
\hline Bartlett' Test of Sphericity & \multicolumn{4}{|c|}{.000} \\
\hline
\end{tabular}




\section{Doğrulayıcı Faktör Analizine İlişkin Bulgular}

Doğrulayıcı faktör analizi (DFA) ile açıklayıcı faktör analizine ait bulguların sınanması, gerektiğinde modelde düzeltmeye gidilmesi, modelin daha kullanışlı ve geçerli kılınması amaçlanmaktadır (Erkorkmaz vd., 2013: 210). Bu kapsamda araştırmada, AFA ile belirlenen sekiz faktörlü yapının geçerliliğinin ve güvenirliliğinin sınanması, kurgulanan yapının ve araştırma modelinin doğrulanması amacıyla veri setine DFA uygulanmıştır. Analiz neticesinde standart faktör yükü 0.40 'ın altında olan 'sürdürülebilirlik işletmemizin temsil ettiği değerlerin içeriğini oluşturur' ifade ölçüm modelinden çıkarılmış ve analiz tekrarlanmıştır. Yinelenen analiz neticesinde 'sürdürülebilirlikten, maliyet azaltma stratejisi olarak yararlanırı' ifadesinin faktör yükünün 0.40 'ın altında olduğu belirlenmiştir. Akabinde tekrarlanan analizler neticesinde 'tur faaliyetine katılan müşterilerimizi yerel seyahat acentalarından gezi satın almaya yönlendiririz' ifadesinin faktör yükünün anlamlı sınırlar içerisinde olmadığı belirlenmiştir. Bahsi geçen ifade çıkartıldığında faktör altında tek ifade olarak kalan 'tur faaliyetlerinde tercih edilen konaklama işletmelerinin sahipliğinin yerel halka ait olmasını önemseriz' ifadesinin başka bir faktör altında yer alıp alamayacağı değerlendirilmiş, fakat ifadenin herhangi bir faktör altında işlevi olmadığ 1 gözlemlenince söz konusu ifadeler birer birer çıkartılarak model yeniden test edilmiştir. Modifikasyonların ardından modelin doğrulanıp doğrulanmadığ elde edilen uyum indeksleri incelenmiştir. Uyum indeksleri DFA sonuçlarının değerlendirilmesinde kullanılan önemli argümanlardandır. Buna göre; bir ölçme modelinin uyum iyiliği değerlerinin uygunluğu ve ölçme modelinin geçerliği için NFI, GFI, AGFI, CFI değerlerinin 0.85 'ten büyük RMSEA değerlerinin 0.08 'den küçük, ki-kare değerinin serbestlik derecesine oranının 5'ten küçük olması gerekmektedir (Şimşek, 2007: 14; Taşkın ve Akat, 2010: 42). Bu bağlamda ölçüm modelinin uyum iyiliği istatistikleri kontrol edilmiştir. Araştırma ölçüm modeline ait uyum indekslerine bakıldığında $\chi 2 / \mathrm{sd}=1.937, \mathrm{NFI}=0.86, \mathrm{CFI}=0.93, \mathrm{GFI}=0.85$, AGFI=083, RMSEA=0.056 ve $\mathrm{p}<0,01$ olduğu görülmektedir. Ölçüm modelinin genel uyumunu yansitan ve 3 'ün altında tespit edilen $\chi^{2} /$ sd değeri, model-veri uyumunda mükemmel bir uyuma işaret etmektedir. Bununla birlikte, $p=, 000$ elde edilmiştir. Söz konusu değer, her bir faktörün oluşumuna katkı sunan değişkenlerin tümünün önemli düzeyde faktör oluşumuna katkı sunduğunu açıklamaktadır. Bununla birlikte, istatistiki değerlerden CFI değerinin iyi uyum ve NFI, GFI ve AGFI değerlerinin kabul edilebilir uyum değerine sahip olduğu tespit edilmiştir. Modelin uyum değerlerinin incelenmesi ve bütünsel anlamlılığının kanıtlanmasının ardından, faktörlerin altında yer alan ifadelerin ilgili oldukları yapıları betimleyip betimlemediklerinin değerlendirilmesi amacıyla faktörlerin yapı güvenirliliği ve açıkladıkları varyans hesaplanmıştır. Huang Wang, Wu ve Wang (2013) ölçüm modelindeki yapının güvenilir olması için yapı değerinin 0,70'ten fazla, açılanan varyans'ın 0,40 ve üzerinde bir değere sahip olmasının kabul edilebilir olduğunu savunmaktadır. Buna göre modelin yapı güvenirliği 0.93 ; açıkladığı varyans 0.53 olarak belirlenmiştir (Bkz: Tablo 3).

Seyahat acentalarının sürdürülebilir turizme yönelik tutum ve davranışlarına yönelik ifadelerin değerlendirmesinde ortaya çıkan görüşler incelendiğinde, birbirinden farklılaşan ortalamalarla karşılaşılmaktadır (Bkz: Tablo 4). Genel itibariyle acentaların, sürdürülebilir turizme yönelik tutum ve davranış ortalamalarının yüksek olduğu belirlenmiştir. Şöyle ki bulgulara göre; acentaların sürdürülebilir turizm faaliyetlerine katkı sundukları ve bu doğrultuda girişimleri olduğu aşikardır. En yüksek ortalamanın görüldügü faktör 'Müşterilerle Iliş̧kiler' $(\bar{x}=4,269)$ olarak belirlenmiştir. Bununla birlikte ortalamanın en düşük olduğu faktör acentaların gönüllü uygulamaları ve bilgi edinme noktasındaki girişimlerini açıklayan 'Destek' $(\bar{x}=2,463)$ faktörüdür. 
Tablo 3: Doğrulayıcı Faktör Analizi Bulguları

\begin{tabular}{|l|c|c|c|}
\hline & $\begin{array}{c}\text { Composite } \\
\text { Reliability (CR) }\end{array}$ & $\begin{array}{c}\text { Average Variance } \\
\text { Extracted (AVE) }\end{array}$ & $\begin{array}{c}\text { Square root } \\
\text { of the AVE }\end{array}$ \\
\hline \multicolumn{1}{|c|}{ Faktörler } & $\mathbf{0 . 9 3}$ & $\mathbf{0 . 5 3}$ & $\mathbf{0 . 7 2 8}$ \\
\hline Hizmet çktılarını geliştirme & 0.91 & 0.58 & 0.762 \\
\hline $\begin{array}{l}\text { Yerel paydaşlarla işbirliği ve paydaş } \\
\text { seçimi }\end{array}$ & 0.88 & 0.60 & 0.775 \\
\hline $\begin{array}{l}\text { Turistik deneyim ve üretimde } \\
\text { ekolojik hassasiyet }\end{array}$ & 0.85 & 0.49 & 0.700 \\
\hline Tedarikçilerle ilişkiler & 0.85 & 0.48 & 0.693 \\
\hline Yerel işbirliği ve etki izleme & 0.78 & 0.54 & 0.735 \\
\hline Müşterilerle ilişkiler & 0.83 & 0.63 & 0.794 \\
\hline Sürdürülebilirliğe destek & 0.62 & 0.41 & 0.640 \\
\hline $\begin{array}{l}\text { Uyum Değerleri= } \chi 2 / s d=1.937 ; \quad p=.000 ; \\
\text { RMSEA } A=0.056\end{array}$ & & & \\
\hline
\end{tabular}

Tablo 4: Seyahat Acentalarının Sürdürülebilir Turizme Yönelik Tutum ve Davranışlarına Bağlı Ortalama (X) ve Standart Sapma Değerleri (SS)

\begin{tabular}{|l|c|c|}
\hline \multicolumn{1}{|c|}{ Sürdürülebilirlik Tutum ve Davranışları } & Ortalama $\left(x^{-}\right)$ & Standart Sapma (SS) \\
\hline Hizmet çıktılarını geliştirme & 4.137 & .650 \\
\hline Yerel paydaşlarla işbirliği ve paydaş seçimi & 3.925 & .708 \\
\hline Turistik deneyim ve üretimde ekolojik hassasiyet & 3.984 & .674 \\
\hline Tedarikçilerle ilişkiler & 4.214 & .643 \\
\hline Yerel işbirliği ve etki izleme & 4.101 & .670 \\
\hline Müşterilerle ilişkiler & 4.269 & .680 \\
\hline Sürdürülebilirliğe destek & 3.874 & .790 \\
\hline
\end{tabular}

\section{SONUÇ ve TARTIŞMA}

\section{Teorik Sonuçlar}

Yapılan bu çalışmada seyahat acentalarının sürdürülebilir turizme yönelik tutum ve davranışlarına yönelik ifadeleri "hizmet çıtılarını geliştirme, yerel paydaşlarla işbirliği ve paydaş seçimi, turistik deneyim ve üretimde ekolojik hassasiyet, tedarikçilerle ilişkiler, tedarikçi tercihi, yerel işbirliği ve etki izleme, müşterilerle ilişkiler, sürdürülebilirliğe destek" faktörleri altında toplanmıştır. Alagöz, Güneş ve Uslu (2015) Erzincan'daki seyahat acentalarına yönelik yaptıkları araştırmada yöneticilerin sürdürülebilirlikle ilgili düşünceleri "geliştirmek, kalite, gelecek, rekabet, ekonomiklik, çevreye duyarlılık ve korumak" şeklinde gruplandırılmıştır. Araştırmada seyahat acentalarının sürdürülebilir turizme yönelik tutum ve davranışlarına yönelik ifadelerin değerlendirmesinde en yüksek ortalamanın görüldüğü faktör 'Müşterilerle İlişkiler' ( $\bar{x}=4,269)$ olarak belirlenmiştir. $\mathrm{Bu}$ bulgu çeşitli araştırmalar tarafından desteklenmektedir (Dönmez ve Çevik, 2010; Erdoğan, 2013; Quintana, Moreno-Gil ve PicazoPeral, 2016). Literatürdeki araştırmalara göre müşterilerle iletişimin kurulması acentalara; rezervasyon yani satışların artışı, kalite, insan kaynakları, yenilik, teknoloji konusunda fayda sağladığı belirtilmektedir (Dönmez ve Çevik, 2010; Miller,2003). Ancak mevcut araştırmada elde bu bulgunun literatürde farklılaştığı çalışmalar da mevcuttur (Saufi, O'Brien ve Picazo-Peral, 
2014). Araştırmada ulaşılan bir diğer sonuca göre seyahat acentalarının sürdürülebilir turizme yönelik tutum ve davranışlarına yönelik ifadelerin değerlendirmesinde ikinci en yüksek ortalamanın görüldüğü faktör 'Tedarikçilerle İlişkiler'dir $(\bar{x}=4,214)$. Çeşitli kaynaklarda da bu bulgu desteklenmektedir (Ashley, Goodwin ve Mcnab, 2005; Gascon, 2009; Travelife, 2012). Ayrıca araştırmalarda tedarikçilerle ilişkilerin gelecekte bir ticari değer olabileceği, yerel halk için gelir artışı ve turistler için de hizmetlere erişim noktasında kolaylık sağlanabileceği gibi yararlarının olduğu belirtilmektedir (Ariana, 2009; Gascon, 2009). Örneğin, Outback Safari'nin faaliyetleriyle ürün satışı ve konaklama ücretleri ile yerel halk her ay yaklaşık olarak 1500 dolar gelir elde etmektedir (http://www.propoortourism.info).

Mevcut araştırmada seyahat acentalarının sürdürülebilir turizme yönelik tutum ve davranışlarına yönelik ifadelerin değerlendirmesinde üçüncü en yüksek ortalamanın görüldügü faktör "Hizmet Çıktılarını Geliştirme' $(\overline{x=4,137)}$ ) olarak belirlenmiştir. Miller'in (2003) yaptığ tespitler çalışmayı destekleyici nitelikte iken, Forsyth (1997) ve Erdoğan (2013) tarafından hazırlanan araştırmalarda ulaşılan sonuçlar mevcut çalışmadan farklılaşmaktadır. Araştırmada seyahat acentalarının sürdürülebilir turizme yönelik tutum ve davranışlarına yönelik ifadelerin değerlendirmesinde "Yerel işbirliği ve etki izleme" ifadesine katılım düzeyi $(\bar{x}=4,101)$ ve "Turistik deneyim ve üretimde ekolojik hassasiyet" ifadesine ise katılım düzeyinin 3.984 olduğu belirlenmiş̧ir. Literatürdeki bir kısım araştırmada bu bulgu desteklenirken (Erdoğan, 2013; Erkol Bayram vd. 2018; Gürbüz, Ayaz ve Apak, 2019) araştırmaların bir kısmında ise bulgunun desteklenmediği belirlenmiştir (Tepelus, 2005; Erdoğan, 2012; Alagöz vd., 2015). Bir diğer sonuca göre seyahat acentalarını sürdürülebilir turizme yönelik tutum ve davranışlarına yönelik ifadelerin değerlendirmesinde "Yerel paydaşlarla işbirliği ve paydaş seçimi" ifadesine katılım düzeyi 3,93'dür. Araştırmadaki bu bulguyu destekleyen çalışmalar (Belisle, 2004; Dönmez ve Çevik, 2010; Erdoğan, 2013; Gürbüz vd. 2019) bulunduğu gibi desteklemeyen (Erkol Bayram vd. 2018) bulgular da mevcuttur. Erdoğan (2013) araştırmasında "Turlarımızda yöre halkından (yerel rehber, aşçı vb.) çalışanlar bulunduruyoruz "ifadesine katılım düzeyi 3,48'dir. Söz konusu araştırmalarda paydaşlarla iletişimin ise; kalite, müşteri memnuniyeti, yenilik gibi faydalar sağladığı belirtilmektedir (Belisle, 2004; Dönmez ve Çevik, 2010). Araştırmada elde edilen bir diğer sonuca göre ortalamanın en düşük olduğu faktör acentaların gönüllü uygulamaları ve bilgi edinme noktasındaki girişimlerini açıklayan 'Destek' ( $\bar{x}=2,463)$ faktörüdür. Söz konusu bulgudan farklı olarak Alagöz vd. (2015) Erzincan'daki seyahat acentalarına yönelik yaptıkları araştırmada yöneticilerin sürdürülebilirlikle ilgili düşüncelerine göre $(\% 33,3)$ ile "geliştirmek" kavramı en düşük önem verdikleri faktördür.

\section{Yönetsel Sonuçlar}

Turizm faaliyetlerine yönelik talebin yaşadığı büyük ölçekli gelişim, turizm sektörünün dünyanın en önemli sektörlerinden biri haline gelmesine olanak tanımaktadır. İstatistiksel veriler turizme faaliyetlerine katılan turist sayısının ve sektörden elde edilen gelirin yıldan yıla arttığını göstermektedir. Bu durum turizm sektörünü ülkelere sağladığı ekonomik gelir noktasında önemli hale getirmektedir. Sektörün ülke ve bölge ekonomilerine sunduğu katkılarla birlikte, turizm faaliyetleri sektörün temel arz çekicilik kaynakları olan doğal çevre ve sosyo-kültürel öğeleri olumsuz etkilediği aşikârdır. Birçok ülke turizmin olumlu ekonomik etkilerini geliştirirken, doğal çevre ve sosyo-kültürel kaynaklar üzerindeki olumsuz etkilerini azaltmanın yollarının aramaktadır. Bu bağlamda uluslararası ve ulusal politikalar belirlenmekte, sektördeki paydaşların turizmde sürdürülebilirliği destekleyen uygulamaları teşvik edilmektedir. Turizm sektörü genel itibariyle birbirine bağlı ancak işletmelerin kendi bünyelerinde faaliyetlerin apayrı olduğu bir yapıya sahiptir. Bu yapıda seyahat acentaları birbirinden ayrı faaliyetler sunan turistik 
bölgeler, konaklama işletmeleri, ulaştırma işletmeleri, yiyecek-içecek işletmeleri, eğlence işletmeleri, hediyelik eşya işletmeleriyle turistler arasında etkileşimi sağlamaktadır. Seyahat acentalarının turistik ve talep arasındaki aracılık ve etkileşimi sağlayıcı bu rolü acentaları turizm sektöründe sürdürülebilirliğin temel bileşenlerinden biri haline getirmektedir. Buna göre seyahat acentaları iç yönetim faaliyetlerinden turistik ürün üretimi ve üretim paydaşlarının tercihlerine kadar tüm faaliyetleriyle turizmde sürdürülebilirliği etkilemektedir.

Araştırma sonuçları incelendiğinde acentalarda sürdürülebilirlik faaliyetlerine yönelik tutum ve davranışların (i) hizmet çıktılarını geliştirme, (ii) yerel paydaşlarla işbirliği ve paydaş seçimi, (iii) turistik deneyim üretim sürecinde ekolojik hassasiyet, (iv) tedarikçilerle ilişkiler, (v) yerel işbirliği ve etki izleme, (vi) müşterilerle ilişkiler, (vii) sürdürülebilirliğe destek boyutlarında kümelendiği görülmektedir. Aynı zamanda acentaların sürdürülebilirliğe karşı tutum ve davranışlarının tüm boyutlarda olumlu olduğu belirlenmiştir. Araştırmada elde edilen bir diğer sonuca göre seyahat acentalarının büyük bir bölümünün sürdürülebilirliği yönlendirecek yazılı politikalara sahip değildir. Acentaların sürdürülebilirliğe karşı olumlu tutum ve davranışlarının uygulamada karşılık bulması adına, sürdürülebilirlik faaliyetlerinin yazılı ilke ve politikalarla desteklenmesi önemlidir. Budeanu'ya (2007) göre acentaların tüm faaliyetlerine yön verecek sürdürülebilirlik politikalarının geliştirilmesi sürdürülebilirlik girişimlerinin olumlu neticelenmesinde başat koşuldur. Acentalarda yazılı sürdürülebilirlik ilke ve politikalarının varlığını teşvik eden başat unsur ise makro düzeyde yazılı ilke ve politikaların varlığıdır (Poon, 1993:154; Budeanu, 2007; Khairat ve Maher, 2012; Arıca, 2013; Lozano vd., 2015; Goffi vd., 2018). Ancak ülkemizde acentaların faaliyetlerine izlek oluşturacak geniş kapsamlı bir yasal düzenleme mevcut değildir. Buna göre yasa düzenleyici olarak devletin, işletmelerin çevre koruma uygulamalarına eğilim göstermesini olanaklı kılacak, yeterli yaptırım gücüne sahip sınırlayıcı ve teşvik edici unsurları barındıran yasal düzenlemeler gerçekleştirmesi elzemdir. Devletin yaptırım gücü yüksek makro ölçekli yasalar belirlemesi, izleme ve denetim faaliyetlerini gerçekleştirmesi, ödüllendirme ve sertifika uygulamaları işletmelerin mikro ölçekli ilke ve politikalar geliştirmesini teşvik edecektir. $\mathrm{Bu}$ sayede ulusal ve yerel düzeyde sürdürülebilirliği destekleyici girişimlerin olumlu karşılık bulması olası hale gelecek, işletmelerin turizmde arz kaynaklarının korunmasına ve yerel unsurların desteklenmesine yönelik girişimleri olumlu neticelenecektir.

Araştırmada elde edilen sonuçlara göre acentaların sürdürülebilirliği sağlamak adına tur üretiminde ekolojik hassasiyet taşıdığı, çevreye duyarlı faaliyet sunan paydaş seçimine önem verdiği görülmektedir. Bununla birlikte işletmelerin bölgeye ve yerel halka fayda sağlayan girişimleri desteklediği görülmektedir. Bu sonuç araştırmada elde edilen bir diğer sonuç olan işletmelerin çalışanlarının büyük bölümünün yerel halktan seçildiği sonucu tarafından desteklenmektedir. TOI (2003) seyahat acentalarında sürdürülebilirliğin beş boyutta gerçekleştiğini açıklamaktadır. Buna göre acentaların iç yönetim, tedarikçilerle ilişkiler, turistik bölgeyle ilişkiler, müşterilerle ilişkiler ve ürün üretim sürecindeki faaliyetleriyle sürdürülebilirliği desteleme olanağı olduğuna dikkat çekmektedir. Buradan hareketle acentaların uluslararası alanda belirlenen standartlar doğrultusunda sürdürülebilirliği destekleyici girişimlerinin olduğu görülmektedir. Buna karşın, turizm sektöründe faaliyetler birden fazla paydaşın işbirliğiyle gerçekleştiğinden, sürdürülebilirliği destekleyici girişimlerin yalnızca bir kısım acenta tarafından gerçekleştirilmesi sürdürülebilirlik girişimlerinin ne düzeyde başarı sağlayacağını tartışmaya açmaktadır. Buna göre bir kısım acentanın sürdürülebilirlik girişimlerinin anlamlı hale gelmesi, başta diğer seyahat acentaları olmak sektörde faaliyet gösteren tüm paydaşların sürdürülebilirliğe bütüncül katılımıyla mümkündür. $\mathrm{Bu}$ noktada konaklama, yiyecek ve içecek, ulaştırma işletmelerinin sürdürülebilir gelişimi destekleyici girişimleri, turistik bölge yönetimlerinin ve bölgedeki halkın süreçteki gönüllüğü ve sürece desteği, müşterilerin duyarlılı̆̆ı sektörel düzeyde sürdürülebilir gelişim amaçlarına 
erişmek bağlamında önemlidir. Buna karşın bir yandan talebin sınırlı olması öte yandan sürdürülebilir turizmi destekleyici faaliyetlerin yüksek maliyetler gerektirmesi sektörel düzeyde sürdürülebilirliğe eğilimi kısıtlı kılmaktadır (Arıca, 2013). Ancak gerek araştırma sonuçlarında gerekse literatürdeki çalışmaların (Budeanu, 2007; Kilipiris ve Zardava, 2012; Arıca, 2013; Alagöz vd. 2015) sonuçlarında da görüldüğü üzere, sürdürülebilirlik faaliyetleri müşteri memnuniyetini geliştirme, pazarlama fırsatları sağlama, olumlu tanıtım, hizmet farklılaştırma gibi hizmet çıtılarını geliştirmektedir. Dolayısıyla sürdürülebilirliğe yönelik girişimlerinin işletmelere uzun vadede ekonomik fırsatlar ve rekabet gücü sağlayacağı aşikârdır. Bu noktada paydaş işletmelerin

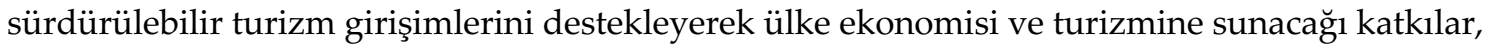
dolayısıyla uzun vadede işletmenin elde edeceği fırsatlara ilişkin farkındalıklarının geliştirilmesi gereklidir. Bu noktada konferans ve toplantılarla sürdürülebilir turizm uygulamalarının faydalarının paydaşlara anlatılması, sivil toplum örgütlerinin sürece katılımı devletin caydırıcılık gücüne sahip ulusal yasal düzenlemelerin yapması ve süreci teşviki, sertifikalandırma girişimleri önem arz edecektir. Benzer şekilde Budeanu (2007) ve Quintana vd., (2016) ifade ettiği üzere müşterilerin sürece destek sunması adına tur faaliyetlerinin tüm süreçlerinde bilgilendirilmesi, farkındalıklarının arttırılması ve müşterilere sürdürülebilirlik kurallarının bildirilmesine ilişkin girişimlerin müşterilerin hassasiyetini arttıracağı aşikârdır. Bütüncül katılım doğal çevre ve sosyo-kültürel kaynakların korunmasını, bu sayede uzun vadede ekonomik sürdürülebilirliğin sağlanmasını olanaklı kılacaktır. Ekonomik faydanın uzun vadeli olması ülke turizminde sürdürülebilirliğin gelişmesine yardımcı olacaktır.

\section{Sınırlılıklar ve Araştırmacılara Öneriler}

Araştırma kapsamında bir bölgede faaliyet gösteren seyahat acentalarından veri derlenmiştir. Bu durum araştırmanın temel sınırlılı̆̆ını oluşturmaktadır. Araştırmanın farklı bölgelerde gerçekleştirilmesi ulusal düzeyde karşılaştırma yapılmasını olanaklı kılabilecektir. Ayrıca araştırmada arz odaklı bir değerlendirme yapılmışır. Gelecek araştırmalarda müşterilerin acentaların sürdürülebilir turizm girişimlerine bakış açısı ve desteğinin değerlendirilmesi bütüncül değerlendirmelerin yapılmasına katkı sağlayabilecektir.

\section{KAYNAKÇA}

Alagöz, G. Güneş, E. and Uslu, A. (2015). Sustainable Tourism Perspective of Hotel Business and Travel Agency Manager: A Field Research, GUEJISS, 6 (14):83-98.

Almunawar, M.N. Muhammad A. and Heru, S. (2013). Crafting Strategies for Sustainability: How Travel Agents Should React in Facing a Disintermediation, Operational Research International Journal, 13: 317-342.

Altunışık, R.; Coşkun, R.; Bayraktaroğlu, S. ve Yıldırım, E. (2012). Sosyal Bilimlerde Araştırma Yöntemleri SPSS Uygulamaları. (7.Baskı). Sakarya: Sakarya Yayıncılık.

Anwar, J. M. (2012). Poverty Alleviation Through Sustainable Tourism: A Critical Analysis of 'ProPoorTourism' and Implications for Sustainability in Bangladesh, Master Thesis, Ritsumeikan Asia Pacific University, Japan.

Arica, R. (2013). Seyahat Acentalarnnda Ekolojik Sürdürülebilir Ürün Yönetimi: Türkiye Üzerine Nitel Bir Araştırma, Yayınlanmamış Yüksek Lisans Tezi, Anadolu Üniversitesi, Eskişehir.

Arica, R. (2017). Seyahat Acentalarında Müşterilerin Üretime Katılım Davranışının Alg̨lanan Hizmet Çıktılarına Etkisi, Anadolu Üniversitesi, Eskişehir. 
Arica, R. (2019). Seyahat Acentalarında Turistik Ürünlerin Kişişelleştirilmesinin Bir Yolu Olarak Müşterilerle Üretim, Türk Turizm Araştırmaları Dergisi, 3:499-516.

Ashley, C. Goodwin, H. and Mcnab, D. (2005). Making Tourism Count for the Local Economy in Dominican Republic: Ideas for Good Practice. Asonahores Travel Foundation, United Kingdom: Sheffield Hallam University.

Ashley, C. and Ashton, J. (2006). Can the Private Sector Mainstream Pro-Poor Tourism? Communicating International Development Research, Id21 Insights, June ,62:1-6.

Aşan, K. ve Yılmazdoğan, O. C. (2012). Yerel Halkın Ev Pansiyonculuğuna Yönelik Girişimcilik Eğilimleri, 13. Ulusal Turizm Kongresi, 6-9 Aralık 2012. Antalya. Ss: 703-717.

Atasoy, M. Reis, S. ve Sancar, C. (2009). Sürdürülebilir Turizm Gelişmesi ve Yayla Turizmi. TMOBB Harita ve Kadastro Mühendisleri Odası 12. Türkiye Harita Bilimsel ve Teknik Kurultayı. Ankara.

Bahar, O. ve Kozak, M. (2005). Küreselleşme Sürecinde Uluslararası Turizm ve Rekabet Edilebilirlik. Ankara: Detay Yayıncılık.

Bagur-Femenias, L. Llach, J. and Del Mar Alonso-Almeida, M. (2013). Is the Adoption of Environmental Practices a Strategic Decision for Small Service Companies: An Empirical Approach, Management Decision, 51(1): 41-62.

Bayram, N. (2012). Yapısal Eşitlik Modellemesine Giriş: Amos Uygulamaları. (3. Baskı). Bursa: Ezgi Kitabevi.

Belisle, D. (2004). Dialogue with Stakeholder, International Trade Forum, 2:18-23.

Budeanu, A. (2005). Impacts and Responsibilities for Sustainable Tourism: A Tour Operator's Perspective, Journal of Cleaner Production, 13(2):89-97.

Byrnes, T. Buckley, R. Howes, M. and Arthur, J. M. (2016). Environmental Management of Boating Related Impacts by Commercial Fishing, Sailing and Diving Tour Boat Operators in Australia, Journal of Cleaner Production,111: 383-398.

Cavlek, C. (2002). Tour Operators and Sustainable Development-A Contribution to the Environment, Journal of Transnational Management Development, 7 (4): 45-54.

Carey, S. Gountas, Y. and Gilbert, D. (1997). Tour Operators and Destination Sustainability, Tourism Management, 18 (7): 425-431.

Choi, H.C. and Sirakaya, E. (2006). Sustainability Indicators for Managing Community Tourism, Tourism Management, 27(6):1274-1289.

Curtin, S. and Busby, G. (1999). Sustainable Destination Development: The Tour Operator Perspective, International Journal of Tourism Research,1:135-147.

Demir, C. ve Çevirgen, A. (2006). Turizm ve Çevre Yönetimi: Sürdürülebilir Gelişme Yaklaşımı. Ankara: Nobel Yayın Dağıtım.

Dimoska, T. and Kocevski, J. (2010). Creating Eco-Tourism Product, 20. Biennial International Congress, New Trends in Tourism and Hospitality Management. Opatija, Croatia.

Doğa Koruma ve Milli Parklar Genel Müdürlüğü (2012). Korunan Alan İstatistikleri. Erişim Linki: http://www.milliparklar.gov.tr/Anasayfa/istatistik.aspx?sflang=tr. Erişim Tarihi: 01.04.2020.

Dönmez, D. ve Çevik, İ. (2010). İşletmelerde Yeniliklerin Kaynağı Olarak Paydaş Diyalogları: Seyahat Acentaları Üzerine Nitel Bir Araştırma, Selçuk Üniversitesi Sosyal Bilimler Enstitüsü Dergisi, 24:189-202. 
Erdoğan, N. (2012). Seyahat Acentelerinin Çevresel İlgilerinin Sürdürülebilirlik Bağlamında Değerlendirilmesi, Tarih Kültür ve Sanat Araştırmaları Dergisi, (1): 247-265.

Erdoğan, N. (2013). Seyahat Acenteleri Örneğiyle Turizmde Sürdürülebilirlik: Ekoetiket, Sertifikasyon ve Akreditasyon Program1, Verimlilik Dergisi, 3:65-92.

Erdoğan, N. (2014). Ekoturizm ve Tur Operatörleri: İlkeler ve Faaliyetlerin Değerlendirilmesi, II. Uluslararası Turizm ve Çevre Sempozyumu, 10-11 Mayıs 2004, İzmir, Turkey.

Erkol Bayram, G. Karaçar, E. Bayram, A.T. ve Ak, S. (2018). Sürdürülebilir Turizm Perspektifinden Destinasyon Yönetimi: Sinop İline Yönelik Bir Araştırma, 1.Uluslararası Turizmde Yeni Jenerasyonlar ve Yeni Trendler Konferansi, 01-03 Kasım 2018, Sapanca, Turkey.

Erkorkmaz, Ü. Etikan, İ. Demir, O. Özdamar, K. ve Sanisoğlu, S. Y. (2013). Doğrulayıcı Faktör Analizi ve Uyum İndeksleri, Türkiye Klinikleri, 33 (1): 210-223.

Falcon, J.M.G. and Muoza, D. M. (1999). The Relationship Between Hotel Companies and Travel Agencies: An Empirical Assessment of the United States Market, the Service Industries Journal, 19(4): 102-122.

Font, X. and Cochrane, J. (2005). Integrating Sustainability into Business: A Management Guide for Responsible Tour Operations. Paris: UNEP.

Forsyth, T. (1997). Environmental Responsibility and Business Regulation: The Case of Sustainable Tourism, the Geographical Journal, 163(3): 270-280.

Fredericks, L. Garstea, R. and Monforte, S. (2008). Sustainable Tourism Destinations: A Pathway for Tour Operators, Blekinge Institute of Technology. Sweden: Karlskrona.

Gascon, J. (2009). Responsible Tourism: A Term Hijacked by Transnational Capital, Contours, 19 (3): 20-22.

Getz, D. and Timur, S. (2005). Stakeholder Involvement in Sustainable Tourism: Balancing the Voices, (Editör) Theobald, W. F.: Global Tourism içinde (ss.230-247) Oxford: Elsevier.

Garrod, B. (2003). Managing Visitors Impacts. (Editör) A. Fyall, B. Garrod and Leask, A. Wanhill, S.: Managing Visitors Attractions New Directions içinde (ss.124-139), Oxford: Elsevier.

Gkoumas, A. (2019). Evaluating a Standard for Sustainable Tourism Through the Lenses of Local Industry, Heliyon, 5: 1-12.

Goffi, G.; Masiero, L. and Pencarelli, T. (2018). Rethinking Sustainability in the Tour-Operating Industry: Worldwide Survey of Current Attitudes and Behaviours, Journal of Cleaner Production. 183: $172-182$.

Gunn, C. A. (1988). Tourism Planning. (2. Edition), New York: Taylor \& Francis.

Gürbüz, A. Ayaz, N. ve Apak, E.C. (2019). Kış Turizminin Sürdürülebilirliği Kapsamında Seyahat Acentası Yöneticilerinin Bakış Açısı: Kayseri Örneği, Uluslararası Türk Dünyası Turizm Araştırmaları Dergisi, 4(1):35-46.

Güzel, F. Ö. ve Ön Esen F. (2019). Seyahat Acentalarının Bölgesel Sürdürülebilir Gelişime Katkısı:Turlar ve Rehberler Kapsamında Travelife Örneği Üzerinden Bir Değerlendirme, Turizm Akademik Dergisi, 6 (1): 205-217.

Hardeman, G.; Font, X. and Nawijn, J. (2017). The Power of Persuasive Communication to Influence Sustainable Holiday Choices: Appealing to Self-Benefits and Norms, Tourism Management, 59: 484-493. 
Holden, A. (2008). Environment and Tourism. (2. Edition), New York: Taylor Francis.

http://www.propoortourism.org.uk, (Erişim Tarihi:10.01.2020).

https://www.prb.org/ecotourismencouragingconservationoraddingtoexploitation/,

(Erişim Tarihi:20. 02.2020).

Huang, C. C. Wang, Y. M. Wu, T. W. and Wang, P. A. (2013). An Empirical Analysis of the Antecedents and Performance Consequences of Using the Moodle Platform, International Journal of Information and Education Technology, 3 (2): 217-221.

Karacan, S. Karacan, E. ve Güngör, Y. (2015). Türkiye Turizmine Yeni Bakışlar: Sürdürülebilir Turizm Ekseninde Çevre Sorunları, I. Eurasia International Tourism Congress: Current Issues, Trends and Indicators, 28-30 Mayıs 2015, Konya, Turkey.

Kaypak, Ş. (2010). Ekolojik Turizmin Sürdürülebilirliği, Alanya İşletme Fakültesi Dergisi, 2(2): 93114.

Kieninger, P.R. Gugerell, K. and Penker, M. (2016). Governance-mix for Resilient Socio-Ecological Production Landscapes in Austria - An Example of the Terraced Riverine Landscape Wachau, (Editör) Ichikawa, K. Subramanian, S. M. and Chakraborty, S.: Satoyama Initiative Thematic Review Vol. 2 içinde (ss.36-49), Tokyo: United Nations University.

Kilipiris, F. and Zardava, S. (2012). Developing Sustainable Tourism in a Changing Environment: Issues for the Tourism Enterprises (Travel Agencies and Hospitality Enterprises), Procedia - Social and Behavioral Sciences, 44: 44-52.

Lozano, J. Arbulú, I. and Rey-Maquieira, J. (2015). The Greening Role of Tour Operators, Environmental Management, 57(1):49-61.

Marin-Pantelescu, A. Tăchiciu, L. Căpușneanu, S. and Topor, D.I. (2019). Role of Tour Operators and Travel Agencies in Promoting Sustainable Tourism, Amfiteatru Economic, 21(52): 654-669.

Miller, G. (2003). Consumerism in Sustainable Tourism: A Survey of UK Consumers, Journal of Sustainable Tourism, 11 (1): 17-39.

Mossaz, A. and Coghlan, A. (2017). The Role of Travel Agents' Ethical Concerns When Brokering Information in the Marketing and Sale of Sustainable Tourism, Journal of Sustainable Tourism, 25(7): 989-1006.

Nylander, M. and Hall, D. (2005). Rural Tourism Policy: European Perspective, (Editör) Hall, D. Kirkpatrick, I. and Mitchell M.): Rural Tourism and Sustainable Business içinde (pp.17-40). Toronto: Channel View Publications.

Özdamar, K. (2016). Eğitim, Sağlık ve Davranış Bilimlerinde Ölçek ve Test Geliştirme Yapısal Eşitlik Modellemesi. IMB SPSS, IBM SPSS AMOS ve MINITAB Uygulamalı. Eskişehir: Nisan Kitapevi.

Poel, D. V. Schamphelaere, J. D. and Wets, G. (2004). Direct and Indirect Effects of Retail Promotions on Sales and Profits in the Do-It-Yourself Market, Expert Systems with Applications, 27:53-62.

Poon, A. (1993). Tourism, Technology and Competitive Strategies. UK: CABI International.

Quintana, T.A. Moreno-Gil, S. and Picazo-Peral, P. (2016). How Could Traditional Travel Agencies Improve Their Competitiveness and survive? A Qualitative Study in Spain, Tourism Management Perspectives, 20:98-108.

Roy, R. (2000). Sustainable Product-Service Systems, Futures, 32: 289-299. 
Saufi, A. O'Brien, D. and Wilkins, H. (2014). Inhibitors to Host Community Participation in Sustainable Tourism Development in Developing Countries, Journal of Sustainable Tourism, 22(5): 801-820.

Schwartz, K. Tapper, R. and Font, X. (2008). A Sustainable Supply Chain Management Framework for Tour Operators, Journal of Sustainable Tourism, 16 (3): 298-314.

Stankova, M. (2010). Bulgarian Tourism and the Niches of Customization, Economics and Management, 15: 760-764.

Sofronov, B. (2017). Impact of Sustainable Tourism in the Travel Industry, Annals of Spiru Haret University, Economic Series, 17(4): 85-94.

Şimşek, Ö.F. (2007). Yapısal Eşitlik Modellemesine Giriş: Temel İlkeler ve LISREL Uygulamaları. Ankara: Ekonoks.

Taşkın, Ç. ve Akat, Ö. (2010). Araştırma Yöntemlerinde Yapısal Eşitlik Modelleme. LISREL İle Marka Değeri Ölçümü Örnekleri. Bursa: Ekin Basım Yayın Dağıtım.

Tepelus, C. (2005). Aiming for Sustainability in the Tour Operating Business, Journal of Cleaner Production, 13: 99-107.

Travelife (2012). Corporate Social Responsibility Training and Certification in the Travel Sector, EU: Project. European Commission Report.

Tsaur, R. C. and Chen, C. H. (2018). Strategies for Cross-Border Travel Supply Chains: Gaming Chinese Group Tours to Taiwan, Tourism Management, 64:154-169.

UNEP (2005). The Tour Operators' Contribution. France: Initiative United Nations Environment Programme.

Usta Ö. (2001). Genel Turizm, İzmir: Anadolu Matbaacılık.

Van Wijk, J. and Persoon, W. (2006). A Long-Haul Destination: Sustainability Reporting among Tour Operators, European Management Journal, 24:381-95.

Weaver, D. (2001). Ecotourism Australia: (2. Edition), New Jersey: John Willey and Sons.

UNWTO (2013). Sustainable Tourism for Development Guidebook, Enhancing Capacities for Sustainable Tourism for Development İ Developing Countries. Spain: World Tourism Organization. 